\title{
Evaluating BEPS
}

\author{
Reuven S. Avi-Yonah \& Haiyan Xu*
}

\begin{abstract}
This article evaluates the recently completed Base Erosion and Profit Shifting (BEPS) project of the G20 and OECD and offers some alternatives for reform.
\end{abstract}

Keywords: tax avoidance, tax evasion, benefits principle

\section{Introduction: The Financial Crisis and Inequality}

The financial crisis of 2008 and the Great Recession that followed have raised anew the problem of how to address a growing inequality both between the rich and everybody else within countries, and between developed and developing countries. Both dimensions of inequality, the intra- and inter-country ones, have risen in this century, and the Great Recession has made both problems worse. The current rise of populism in both the US and Europe and the vehement reactions to a tide of migrants from poorer to richer countries show how these two problems are intertwined. ${ }^{1}$

In the year 2000, the first author wrote about the challenge that globalisation and tax competition pose to the fiscal viability of the post-World War II welfare state. ${ }^{2}$ He pointed out that if tax evasion by rich individuals and tax avoidance by multinational corporations is allowed to undermine the ability of both developed and developing countries to provide adequate social insurance for their citizens, a violent reaction against globalisation may ensue that risks ending this era of opening borders, just like World War I ended the previous era of globalisation a century ago. Today we worry that the lack of adequate response to the Great Recession is leading to the rise of violent anti-globalisation sentiments on both the right and the left, embodied in the US by the success of Bernie Sanders and Donald Trump and in Europe by an even more virulent rejection of the open border policies the EU has stood for. ${ }^{3}$

Reuven Avi-Yonah is Irwin I. Cohn Professor of Law, the University of Michigan. Haiyan $\mathrm{Xu}$ is Professor of Law, University of International Business \& Economics, Beijing; SJD candidate, the University of Michigan. The authors would like to thank participants in workshops at NYU and Duke Law schools for comments, and Itay Peer for invaluable research assistance.

1. See, e.g. P. Noonan, 'Trump, Sanders and the American Rebellion', WSJ, 2/11/16; available at: <http://on.wsj.com/1QavpWY>.

2. R. Avi-Yonah, 'Globalization, Tax Competition, and the Fiscal Crisis of the Welfare State', 113 Harv. L. Rev. 1573 (2000).

3. Noonan, above n. 1; <www.bbc.com/news/world-europe-24583286>.
It is imperative for the West to find ways to strengthen the ability of the state to provide adequate social insurance and reduce inequality before these forces lead to the closing of the borders and to pressures that could result in the end of the current era of globalisation. But the response so far has unfortunately not been adequate. Following the financial crisis and ensuing austerity, politicians discovered the problem of tax avoidance. On the corporate tax avoidance front, the OECD and G20 launched the Base Erosion and Profit Shifting (BEPS) project in 2013, and this has in October 2015 culminated with the release of a series of action steps that the OECD and G20 countries have undertaken to adopt. ${ }^{4}$ OECD Secretary-General Angel Gurria has stated that

Base erosion and profit shifting affects all countries, not only economically, but also as a matter of trust. BEPS is depriving countries of precious resources to jump-start growth, tackle the effects of the global economic crisis and create more and better opportunities for all. But beyond this, BEPS has been also

On BEPS see, e.g., P. Saint-Amans and R. Russo, 'The BEPS Package: Promise Kept', 70 IBFD Bull. Int. Tax. 4 (2016); H.J. Ault, 'Some Reflections on the OECD and the Sources of International Tax Principles'. Reprinted from 70 Tax Notes Int. 12 (2013), at 1195; Working Paper of the Max Planck Institute for Tax Law and Public Finance No. 2013-03. Available at SSRN: <http://ssrn.com/abstract=2287834> or <http://dx. doi.org/10.2139/ssrn.2287834>; D. Dharmapala, 'What Do We Know about Base Erosion and Profit Shifting? A Review of the Empirical Literature,' Illinois Public Law Research Paper No. 14-23; University of Chicago Coase-Sandor Institute for Law \& Economics Research Paper No. 702 (2014). Available at SSRN: <http://ssrn.com/abstract=2373549> or <http://dx.doi.org/10.2139/ssrn.2373549>; Y. Brauner, 'What the BEPS?', University of Florida Levin College of Law Research Paper No. 15-40 (2014). Available at SSRN: <http://ssrn.com/abstract=2408034> or <http://dx.doi.org/10.2139/ssrn.2408034>; H.J. Ault, W. Schoen \& S. Shay, 'Base Erosion and Profit Shifting: A Roadmap for Reform', 68 Bull. Int. Tax., 275 (2014); Boston College Law School Legal Studies Research Paper No. 324. Available at SSRN: <http://ssrn.com/abstract= 2459646>; D. Dharmapala, 'Base Erosion and Profit Shifting: A Simple Conceptual Framework', University of Chicago Coase-Sandor Institute for Law \& Economics Research Paper No. 703 (2014). Available at SSRN: <http://ssrn.com/abstract=2497770>; R.J. Vann, ‘Policy Forum: The Policy Underpinnings of the BEPS Project-Preserving the International Corporate Income Tax?' 62(2) Can. Tax J. 433, at 433-41 (2014); Sydney Law School Research Paper No. 14/77. Available at SSRN: <http://ssrn.com/abstract=2483619>; D. Shaviro, 'The Crossroads versus the Seesaw: Getting a "Fix" on Recent International Tax Policy Developments', NYU School of Law, Public Law Research Paper No. 15-20, NYU Law and Economics Research Paper No. 15-11 (2015), Available at SSRN: <http://ssrn.com/abstract=2605144> or <http://dx. doi.org/10.2139/ssrn.2605144>; A.H. Rosenzweig, 'Building a Framework for a Post-BEPS World', 74 Tax Notes Int. No. 12 (2014). Available at SSRN: <http://ssrn.com/abstract=2463259>; I. Grinberg, 'Breaking BEPS: The New International Tax Diplomacy', Georgetown University Law Center Draft (1 September 2015). Available at SSRN: <http:// ssrn.com/abstract=2652894> or <http://dx.doi.org/10.2139/ssrn. 2652894>. 
eroding the trust of citizens in the fairness of tax systems worldwide. The measures we are presenting today represent the most fundamental changes to international tax rules in almost a century: they will put an end to double non-taxation, facilitate a better alignment of taxation with economic activity and value creation, and when fully implemented, these measures will render BEPS-inspired tax planning structures ineffective. ${ }^{5}$

Is Mr. Gurria justified in his optimism? We do not think so. These efforts are commendable and to some extent have an impact. But in our opinion they are inadequate. The basic problem is that they take as a given the fundamental consensus underlying the international tax regime, also known as the 'benefits principle'. Under the benefits principle, active (business) income should be taxed primarily at source while passive (investment) income should be taxed primarily at residence. ${ }^{6}$ This compromise between the claims of residence and source countries was reached in 1923 and still serves as the foundation of the international tax regime. ${ }^{7}$ It is embedded in over 3,000 bilateral tax treaties and in the domestic laws of the US and most other countries. Not surprisingly, it is also reflected in BEPS, which is an attempt to improve source-based taxation of active income. $^{8}$

In our opinion, the benefits principle should be reconsidered, because the reliance on source-based taxation for active income and residence-based taxation for active income requires cooperation by too many jurisdictions. The problems of BEPS stem from its reliance on the benefits principle.

In the case of active income, the justification for taxation at source has been that most such income is earned by corporations that have no fixed residence. However, since the 1980s, tax competition has led many source jurisdictions to offer tax holidays to multinationals, and residence jurisdictions are reluctant to tax their multinational on their global income so as not to put them at a competitive disadvantage. The result has been that most multinationals are not taxed currently at source or at residence.

Two recent examples can be used to illustrate the problem of tax avoidance on cross-border income: ${ }^{9}$

As of the end of 2015, US multinationals had over $\$ 2$ trillion in offshore profits in low-taxed jurisdictions. ${ }^{10}$

5. OECD, Centre for Tax Policy and Administration, 'OECD presents outputs of OECD.G20 BEPS Project for discussion at G20 Finance Ministers' meeting, 5 October 2015

6. On the benefits principle and its origins, see R. Avi-Yonah, 'The Structure of International Taxation: A Proposal for Simplification', 74 Texas L. Rev. 1301 (1996); R. Avi-Yonah, 'International Taxation of Electronic Commerce', 52 Tax L. Rev. 507 (1997); R. Avi-Yonah, Advanced Introduction to International Tax Law (2015), ch. 1.

7. Avi-Yonah (1996), above n. 6.

8. On the ideas behind BEPS, see, e.g. Ault (2013), above n. 4, at 1195.

9. These examples are based on R. Avi-Yonah, 'International Tax Evasion and Avoidance: What Can Be Done?' The American Prospect (2016).

10. Available at: <http://ctj.org/ctjreports/2015/07/21_trillion_in_ corporate_profits_held_offshore_a_comparison_of_international_tax_ proposals.php\#.VroUufkrLmg>.
This amount, which translates to about $\$ 700$ billion in US taxes avoided, is mostly income that was economically earned in the US and shifted offshore to jurisdictions like Singapore, Ireland or Luxembourg, which have effective tax rates in the single digits.

How do the multinationals do it? A couple of examples can suffice. Apple, Inc. is the world's largest company by market capitalisation. Most of its billions in profits relate to intellectual property developed at its headquarters in Cupertino, California. But for tax purposes, most of the profit is booked in its Irish subsidiaries - let's call them Apple Ireland. ${ }^{11}$

Some of the profit shifting is achieved through a 'cost sharing agreement'. Cost sharing is a concept developed in IRS regulations in the 1980 s, but which became more significant due to the increasing importance of intellectual property. The idea behind cost sharing is this: When a US multinational begins a new research project (for example, a search for a drug to treat a certain disease), it can agree to share the costs of development with its offshore subsidiaries. Then, if the project is successful, the parties share the profits in the same proportions. For example, if Apple Ireland contributed $80 \%$ of the costs of developing the iPhone 6 , it would get $80 \%$ of the profit. Importantly, none of the actual work is done by Apple Ireland. Apple just gives Apple Ireland the money and Apple Ireland pays it back as its contribution to the research costs.

Why would the IRS regulations permit this? Because if the research failed, then the taxpayer would lose its ability to deduct the costs sent offshore. The more of the cost sent offshore, the more deductions would be at risk. So the IRS thought there was a natural limit to taxpayer's willingness to share costs with offshore affiliates.

That analysis may have been true for Big Pharma, which usually waits to enter into cost sharing with an offshore affiliate until a drug has passed its initial trials and is well on its way to a patent, and then battles the IRS over valuation issues at the time the cost-sharing agreement was executed. But the same analysis makes no sense for Apple, since if there is anything certain in business, it is that a new version of the iPhone will sell.

There is another trick involved in Apple Ireland's profitability. Another portion of its profits derive from countries where Apple sells the iPhones. Apple Ireland licenses the right to use Apple's brand and intellectual property to Apple affiliates in other countries. Those affiliates in turn pay Apple Ireland hefty royalties, which operate to shift the sales profits gained in those countries to Ireland.

Before 1997, such a scheme would not have worked, because the royalties received by Apple Ireland would have triggered a tax in the US under so-called Subpart F. But in 1997 the Clinton Administration adopted a rule called 'check the box'. Under check the box, Apple Ireland can treat all of its foreign affiliates as if they did not exist as separate entities for US tax purpo-

11. Available at: <https://www.gpo.gov/fdsys/pkg/CHRG-113shrg81657/ pdf/CHRG-113shrg81657.pdf>. 
ses and treat the money they paid to Apple Ireland as income earned in Ireland. The result is that for US tax purposes there are no royalties and no US tax triggered by them, because Apple Ireland treats the money as its own sales income.

The Obama Administration came in promising to repeal check the box; this was the biggest international revenue raiser in the first Obama budget. But by November 2009 the Administration recanted under pressure from the multinationals. On December 18, 2015, President Obama signed into law a five-year extension of a provision (first enacted by a Republican Congress as a 'temporary' measure in 2006) that enshrines check the box in the tax law.

Finally, the Senate hearing revealed two Irish-specific tricks used by Apple. Ireland has a tax rate of $12.5 \%$, far below the US rate of $35 \%$. But Apple did not want to pay even $12.5 \%$. Its solution was ingenious: For US tax purposes, Apple Ireland is treated as an Irish company because it is incorporated in Ireland, so it is not taxed by the US. But for Irish tax purposes, Apple Ireland was treated as an American company because it is 'managed and controlled' from California. As a result, Apple Ireland claimed it was a tax resident nowhere. On top of that, it negotiated a sweetheart tax deal with Ireland for its Irish income that resulted in its paying a tax rate of less than $2 \%$.

These types of tricks are used by most US multinationals. If the primary driver of value of a US multinational is intellectual property developed in the US, the Apple scheme can simply be replicated.

But what if the value derives from more traditional, tangible items? Some US multinationals do pay higher taxes (e.g. the car companies). But others try to avoid tax nevertheless. Caterpillar, Inc. is a good example. ${ }^{12}$

Caterpillar does not make a lot of money on the heavy equipment it manufactures. But it makes a bundle on replacement parts, because once you buy a Caterpillar bulldozer, you will need parts, which you can obtain only from Caterpillar at a huge mark-up. Caterpillar prides itself on its ability to deliver parts within 24 hours anywhere in the world, including the Arctic tundra (where its equipment is used in mineral extraction). Before 1998, Caterpillar bought the parts from unrelated manufacturers and stored them at its warehouse in Morton, Illinois. When a dealer requested a part for a customer overseas, Caterpillar 'sold' (but did not actually ship) the part to a Swiss subsidiary, which in turn sold the part to the unrelated dealer.

The problem, according to accounting firm PriceWaterhouseCoopers, was that Caterpillar's sale of the part to its Swiss subsidiary triggered US tax. Much better, PwC said, would be if the parts were sold by the manufacturer directly to the Swiss subsidiary, which could then sell it to the dealer.

Fine, said Caterpillar, but we do not want to change our operations. So in exchange for $\$ 60$ million in fees, $\mathrm{PwC}$ came up with a way to lower Caterpillar's US tax without changing its operations. PwC's solution was for the manufacturers to bill the Swiss subsidiary for the parts but continue to ship them to the Illinois warehouse, which continued to transport them to Caterpillar's foreign customers. If the parts were shipped overseas, they were deemed to have been 'owned' by the Swiss subsidiary, and $\mathrm{PwC}_{w}$ devised a virtual inventory to track them even though the parts were indistinguishably commingled in the warehouse. The result was that Caterpillar continued to run its parts business from the US, but declared $85 \%$ or more of the parts profits in Switzerland.

The IRS has now challenged this billing arrangement, which resulted in shifting some $\$ 2.4$ billion in Caterpillar profits from the United States to Switzerland. A Grand Jury has issued subpoenas under a criminal investigation for tax fraud.

But the disturbing fact is that the whole story would not have come to light but for a whistle-blower, who alerted both the US Senate Permanent Subcommittee on Investigations and the IRS. And while Caterpillar is facing a court challenge, in most cases of corporate tax avoidance, like Apple, the IRS' hands are tied because what Apple did may have been legal under the US tax code.

The fundamental problem of BEPS stems from its reliance on the benefits principle. BEPS seeks to bolster source-based taxation of active income, but it does not apply to countries outside the OECD/G20, and its scope is quite limited as discussed below.

To preserve the income tax in the 21 st century, multilateral solutions are needed. BEPS is multilateral, but it is hampered by the fact that there are too many source jurisdictions for active income. If we reversed the benefits principle so that passive income is taxed primarily at source and active income at residence, far fewer jurisdictions will need to cooperate.

For passive income, the number of source jurisdictions is much smaller than residence jurisdictions. Because most individuals are relatively risk averse, portfolio investment flows overwhelmingly to a small number of countries - the US, the EU and Japan. Even the BRICS mostly attract portfolio investment through mutual funds that are relatively easy to tax. Thus, if the 'big three' can coordinate to reinstate a withholding tax on interest, dividends and royalties flowing from them, most of the problem of taxing passive income can be solved. Crucially, money cannot stay in tax havens and earn decent rates of return, so the cooperation of tax havens is not needed.

For active income, about $90 \%$ of large multinationals are headquartered in the G20, and none of those countries has a tax rate below $20 \%$, so if they taxed their multinationals currently on a coordinated basis and 
restricted the ability to move out, most of the problem would be resolved. ${ }^{13}$

We would therefore suggest that we reconsider the benefits principle in light of the reality of globalisation. We should tax passive income primarily at source and active income primarily at residence.

Importantly, like under current rules, this does not preclude the alternative. Once passive income is taxed at source, taxpayers may be able to credit the tax upon declaring it to their residence country. And once active income is taxed at residence, a credit can be given to source country taxes if the source country responds to the limitation of tax competition by re-imposing its tax. But the key is that the income has already been taxed, so that no double non-taxation ensues even if taxpayers do not declare the income (in the case of passive income, where the residence rate may be higher) or source countries choose not to tax in the case of active income.

The following unpacks this analysis in more detail. Section 2 analyses the BEPS response to corporate tax avoidance and its shortcomings. Section 3 develops the alternative: Taxing passive income primarily at source and active income primarily at residence. Section 4 concludes.

\section{The Limits of the BEPS Project}

On 5 October 2015, the OECD and G20 released the final BEPS package of 13 reports, which cover 15 actions. ${ }^{14}$ It was only two years since the G20 leaders endorsed the ambitious and comprehensive Action Plan to address BEPS at the meeting in St. Petersburg on 5-6 September 2013.

The BEPS package represents the first substantial - and overdue - renovation of the international tax standards in almost a century. ${ }^{15}$ The BEPS package is an unprecedented turning point in the history of international tax law. The mission of the BEPS package is to align the location of taxable profits with the location of economic activities and value creation. Some generally accepted principles of international tax law, including the single tax principle, the benefit principle, the anti-discrimination principle and the transparency principle have been reflected in many respects.

Despite considerable progress, there are many shortcomings with the BEPS project due to the short twoyear framework. Hence, the BEPS project is not the final destination of international tax law reform. In fact,

13. For the location of the world's 100 largest multinationals, see the Forbes 2000 list, available at: <www.forbes.com/sites/liyanchen/2015/05/ 06/the-worlds-largest-companies/\#4ebf4ea14fe5> (89\% are in G20 countries); for the tax rates of the G20, see <https://www.flickr.com/ photos/hmtreasury/7003545741>

14. Available at: <www.oecd.org/tax/beps-2015-final-reports.htm>.

15. OECD, 'Explanatory Statement', OECD/G20 Base Erosion and Profit Shifting Project (2015), at 5 it is the first step towards the modernisation of global tax governance in the long run.

\subsection{New Shoes on the Old Road: An Old} Approach for the New Destination

The primary problem with the BEPS project is that although the new destination has been redefined, new principles and new rules have not been truly established for the new direction, and the old principles have been strengthened by a patch up of current rules.

The core principle of international tax law is the single tax principle, which requires eradication of both double taxation and double non-taxation. ${ }^{16}$ Unfortunately, both the governments and the MNEs have been active in fighting against the double taxation, and have ignored another danger of double non-taxation. Therefore, the main theme of traditional international tax law has been eradication of double taxation, instead of double nontaxation.

Based on the single tax principle, the mission of the BEPS project is to prevent and eliminate the double non-taxation. As the G20 leaders pointed out the new principle, 'profits should be taxed where economic activities deriving the profits are performed and where value is created'. ${ }^{17}$ Therefore, the new direction of international tax law reform in the context of BEPS project is to safeguard the single tax principle by fighting against the BEPS.

It is well known that the rickety international tax regime, including rules and underlying principles, is one of the primary root causes of BEPS opportunities. ${ }^{18}$ Therefore, the new direction demands revolutionary changes to current approaches. The ideal roadmap for the BEPS project is supposed to replace the old principles with a new principle, and to redesign the rules based on the requirement of the new principle.

Unfortunately, many old principles of international tax law have been preserved and continued in the final BEPS package. The mixture of new principle and old principles has substantially compromised the value of the new principle, and made the legal reform of international tax look more like the patch-up of existing rules and principles. The reason is pretty obvious. On the one hand, it is impossible to abolish or even reconsider the dysfunctional current rules, which have been favoured by some large countries and MNEs. On the other hand, it is mandatory to change the current rules to some extent, because of the emerging political pressure against BEPS schemes.

Given the fact that two years are very short for serious in-depth research, debate and negotiation, given the

16. Ault (2013), above n. 4; R. Avi-Yonah, 'Who Invented the Single Tax Principle? An Essay on the History of US Treaty Policy', 59 NYLS L. Rev. 305 (2015); R. Avi-Yonah, 'Full Circle? The Single Tax Principle, BEPS, and the New US Model', $U$ of Michigan Public Law Research Paper No. 480 (2015); U of Michigan Law \& Econ Research Paper No. 15-019. Available at SSRN: <http://ssrn.com/abstract=2673463> or <http://dx. doi.org/10.2139/ssrn.2673463>.

17. Tax Annex to the St Petersburg Declaration, September 2013

18. Ault (2013), above n. 4. Hugh Ault was the principal theoretical contributor to the BEPS project in his role as senior adviser to OECD. 
strong tradition and interest groups desire to keep the continuity of old principles, given the global voice for closing up the BEPS opportunities, the architect of the BEPS project has no choice but to patch up some loopholes of current rules, instead of fundamental restructuring of current regime. ${ }^{19}$

As a result, complete renovation of current international tax law did not happen, and genuine new rules guided by the new principle have not been formulated. Moreover, the patch-up work has produced many more complex, discretionary, uncertain, costly and in many cases contradictory rules. ${ }^{20}$ There are two possible negative consequences. First, it is difficult to translate all the new rules into the reality. Second, even if the BEPS project is implemented as outlined and promised in the book, it is still possible for the creation of either new BEPS opportunities on the part of MNEs, or arbitrariness on the part of tax authorities.

In addition to adhering to the independent entity principle and rejection of the new principle of single unitary entity, the BEPS project is also silent on the basic concepts of residence and source, and where profit should be considered to be earned. As the existing rules based on the old principles have been strengthened, and new rules based on the new principle have not been established, the BEPS project is not so revolutionary and fundamental as it appears at the first sight.

The ironic fact is that the patch up of current rules in the BEPS project was made in the name of new mission and new principle. However, because of the inconsistencies and conflicts between the new principle and old principles, the new principle of international tax law has been compromised or undermined by the strengthened current rules based on old principles. Without the support of new principle and new rules, it is very challenging to achieve the new destination of aligning the taxation of MNE profits with economic activity.

2.2 The Survival and Continuity of Notional and Illusionary Independent Entity Principle and Arm's Length Principle

The traditional international tax law is designed and interpreted based on the assumption that the various constituent entities or members of MNE group are independent of each other and conduct transactions with each other at arm's length. ${ }^{21}$

While criticising the independent entity theory as a fundamental flaw of the existing rules, the BEPS Monitoring Group identified a new but implied approach in the G20 mandate to treat the corporate group of an MNE as a single firm, and ensure that its tax base is attributed

19. Ault (2013), above n. 4

20. See detailed discussion below, and the report card prepared by the BEPS Monitoring Group, available at: <https://bepsmonitoringgroup. wordpress.com/2015/10/05/overall-evaluation/>

21. R. Avi-Yonah, 'The Rise and Fall of Arm's Length: A Study in the Evolution of U.S. International Taxation', 15 Virginia Tax Rev. 89 (1995); R. Avi-Yonah, 'Between Formulary Apportionment and the OECD Guidelines: A Proposal for Reconciliation', 2 World Tax J. 3 (2010); R. AviYonah and I. Benshalom, 'Formulary Apportionment - Myths and Prospects', 3 World Tax J. 371 (2011). according to its real activities in each country. ${ }^{22}$ This means that the new destination of taxing MNEs 'where economic activities take place and value is created' is unlikely to be achieved, without treating the MNE group as a single firm.

We also support the single unitary entity principle. ${ }^{23}$ In our view, the G20 mandate could be interpreted as both a new direction and a new guiding philosophy, which requires all the BEPS actions to serve the purpose of taxing MNEs where economic activities take place and value is created in the most efficient manner. Guided by the brand new philosophy, the principle of single unitary entity and the basic concepts of residence and source need to be established as the cornerstones to support the design, interpretation and implementation of new measures in the BEPS package.

Unfortunately, the BEPS project refused to make the implied principle explicit, but has continued to emphasise the independent entity principle, while attempting to counteract its harmful consequences. Consequently, the BEPS outputs fail to provide a coherent and comprehensive approach, and offer instead proposals for a patch-up of existing rules, making them even more contradictory and complex. ${ }^{24}$

According to our observation, virtually all the new rules of the BEPS package are still built on the notional principle of independent entity. ${ }^{25}$ By its very nature, the untouchable principle of arm's length ultimately derives from the root of independent entity theory. In addition, many other flawed rules including weak CFC rule; territorial and deferral systems are also indirectly but closely connected with the independent entity principle.

The orthodoxy of independent entity taxation has two basic assumptions. First, the members of the MNE group are regarded as equal, separate and independent legal persons. Namely, the members of MNE group are reasonable legal entities. From the perspective of corporate law, the fiction of independent entity in the context of a corporate group derives from the orthodoxy of shareholder's limited liability and the corporate independent status as legal persons in the traditional corporate law. Second, the contracts between the related parties in the corporate group are freely negotiated at arm's length, and the terms of the contract are fair and reasonable dealings. ${ }^{26}$ In short, both the entities and the transactions in the corporate group are reasonable, therefore legal and moral.

22. The BEPS Monitoring Group (BMG), 'Overall Evaluation of the G20/ OECD Base Erosion and Profit Shifting (BEPS) Project', available at: $<$ https://bepsmonitoringgroup.wordpress.com.

23. For a detailed proposal with legislative language, see R. Avi-Yonah, K. Clausing \& A. Durst, 'Allocating Business Profits for Tax Purposes: A Proposal to Adopt a Formulary Profit Split', 9 Fla. Tax Rev. 497 (2009); R. Avi-Yonah, 'A Proposal for Unitary Taxation and Formulary Apportionment to Tax Multinational Enterprises', in P. Dietsch and T. Rixen (eds.), Global Tax Governance (2016) at 289. We support these proposals, but given the strong opposition of both OECD and the US Treasury, we regard them as longer-term prospects than the proposal in this article.

24. The BEPS Monitoring Group, above n. 22

25. See BEPS Action Plan 8-10.

26. See Avi-Yonah, Clausing \& Durst, above n. 23. 
However, the two beautiful and attractive assumptions do not make sense, and they do not really exist in the commercial reality. The primary commercial reality is that a multinational corporate group operates more like a single, unitary entity or enterprise rather than separate independent entities or enterprises. This is made possible by the controlling power of the parent corporation. As traditional international tax law stubbornly insists on the old concept of independent entity, the MNEs have been encouraged to incorporate dozens and even hundreds of affiliates all over the world to undertake aggressive BEPS schemes. ${ }^{27}$ The more subsidiaries or members in the MNE family, the stronger the parent corporation in reducing the overall transaction cost, and advance the profitability of the group as a whole. Why? The answer is very simple. All the commercial activities of the subsidiaries and affiliates are under the effectively direct or indirect control from the parent corporation. Therefore, the profits or benefits could be unlimited by separate but coordinated operations of business under the uniform controlling power. On the other hand, the principle of independent entity could better protect the MNEs from unlimited risks and liabilities of group members towards bona fide third parties including the tax authorities. Therefore, the legal risks and liabilities of corporate group are limited by law, because there is no joint and several liability between and among the group members unless otherwise agreed by the corporate group members.

Because of the controlling power of the parent corporation on the top of the pyramid of the complicated corporate structure, like a smart spider at the centre of a grand network of corporate groups, it is unlikely to find real arm's length transaction in the reality. ${ }^{28}$ In fact, the related party contracts within the corporate group are always concluded without seriously free, competitive and transparent bargainings and negotiations.

If the BEPS project is designed on the principle of single unitary entity, the BEPS counter-measure will be much more simple and effective, as inter-group transactions will be disregarded, and the profit or tax base will be attributed to its real activities that generate the profit and create the value in the jurisdictions.

Unfortunately, many actions of the BEPS project, including but not confined to Action 2 on hybrid mismatches, Action 7 on PE, and Actions 8-10 on transferring pricing, heavily rely on the legal fictions of independent entity and arm's length transaction. ${ }^{29}$

\subsection{The Survival and Continuity of the Problematic Benefit Principle}

The OECD declared that, the goal of BEPS package is 'to tackle BEPS structures by comprehensively addressing their root causes rather than merely the symptoms. Once the measures are implemented, many schemes facilitating double non-taxation will be curtailed. ${ }^{30}$ Therefore, a key question is whether all root causes, instead of symptoms, have been addressed?

In our opinion, one of the root causes is traditional benefit principle, which has guided the allocation of global profits in the past decades, and has created many BEPS opportunities. Unfortunately, the BEPS project failed in replacing the benefit principle. Instead, the BEPS package was still designed based on residence jurisdictions for passive income and source jurisdictions for active income.

As articulated in this article, our argument is that BEPS concerns will be more effectively tackled if passive income is primarily taxed at source and active income is primarily taxed at residence. This new philosophy will help to build a new international tax governance framework of win-win, which will benefit both developed countries and developing countries. Moreover, the conflicts between the domestic demand for tax revenue and domestic policy to attract foreign direct investment will be better balanced, and the MNEs and domestic firms will be offered a level playing field.

Many scholars have realised the significance of the renovation of basic principles of current international tax law. As Mindy Herzfeld argued,

attempts at coordination cannot be successful unless there is agreement on an underlying set of principles for allocating the revenue of global citizens (including natural persons and legal entities). A more rigorous effort to develop such a clear and agreed upon set of principles which rests on economic, philosophic and fairness grounds is needed. ${ }^{31}$

\subsection{Limited Inclusiveness and Multilateralism}

Global challenges need global solutions. BEPS, as a global concern, is made possible by uncoordinated tax rules at domestic and international levels. Therefore, the global solutions need to be based on inclusive and multilateral global governance. This means each and every country should be offered equal opportunity and equal weight to shape the outcome of the global solutions. $^{32}$

Although OECD/G20 have made great efforts in organising many non-member countries and NGOs to participate in the development of the BEPS package, the inclusiveness and multilateralism of the BEPS project is limited for a number of reasons.

First, the undisputed fact is that major OECD countries dominated the formulation of the BEPS package in the process of discussions and negotiations. As OECD countries are all developed countries, it is inevitable that the BEPS project is mainly a result of compromise between the rich countries. For instance, weak measures

30. OECD, above n. 15, at 5 .

31. M. Herzfeld, 'The Limits of Tax Coordination', Working Draft (11 October 2015).

32. This does not of course mean that every country will in fact participate, only that they should be given the opportunity to do so. 
on CFCs, interest deductibility and innovation box schemes are favoured particularly by the $\mathrm{UK}^{33}$

Second, although over 60 countries were directly involved in the process of the BEPS project, they only account for less than one-third of 193 UN members. ${ }^{34}$ As MNEs have their taxable presence around the globe, including the non-participating countries, the effectiveness of the BEPS project is very limited. The tax competitions between participating countries and non-participating countries will continue. The race to the bottom and the unilateral actions taken by any jurisdiction could hurt all the countries in the world.

Third, although some developing countries were consulted for the BEPS project, it does not necessarily mean that their core proposals were finally accepted by the BEPS package. As observed by independent commentators, some key OECD countries opposed and succeeded in blocking the institutional reform proposal from developing countries at the 3rd International Conference on 'Financing for Development'. ${ }^{35}$

Fourth, less influential participating countries and more than 120 non-participating counties might be hurt due to the effect of negative spillover arising from the implementation of the BEPS project in the future. They are weak not only because of their limited influence in the renovation of the current rules, but also because of their limited experience and resources to enforce the BEPS actions.

Fifth, the process of public debate and consulting was relatively insufficient. BEPS Monitoring Group, an active tax justice advocate, complains that they have been vastly outnumbered by the army of paid tax advisers and representatives of multinational enterprises. ${ }^{36}$ Although stakeholder interest, including invaluable interactions with business and civil society, saw more than 12,000 pages of comments received on the 23 discussion drafts published and discussed at 11 public consultations, ${ }^{37}$ it is unknown to what extent these valuable proposals have been adopted by the BEPS package. More importantly, detailed reasons for rejecting different proposals have not been published.

Given the fact that it is impossible to guarantee that countries and stakeholders really had the equal opportunity to influence and shape the outcome of the BEPS package on really equal footing, OECD and/or G20 is not the truly global platform for comprehensive reform of international tax law. To transform the current BEPS project into truly global, coherent, coordinated and inclusive actions, the UN should undertake the leadership in the next stage of international tax law reform.

The third paragraph of Article 1 of the Charter of the $\mathrm{UN}$ recognises that the third purpose of the $\mathrm{UN}$ is to achieve international cooperation in solving international problems of an economic, social, cultural or humanitarian character. The fourth paragraph of Article 1 of

33. The BEPS Monitoring Group, above n. 22, at 3.

34. Available at: <www.un.org/depts/dhl/unms/whatisms.shtml\#states>.

35. The BEPS Monitoring Group, above n. 22

36. Ibid.

37. OECD, above n. 15 , at 5 . the Charter of the UN recognises that its fourth purpose is to 'be a centre for harmonizing the actions of nations in the attainment of these common ends'.

We believe that the UN will be more qualified, impartial, transparent, credible and influential than the OECD/G20 in rewriting and renovating the international tax rules including the BEPS counter-measures. All UN members have the right to be heard and represented in the process of international tax law reform. ${ }^{38}$ As the working group of the UN, the UN Tax committee is expected to make great difference in this regard.

We urge that the UN Convention of Anti-BEPS should be made the cornerstone of the global response to BEPS in a more coherent, inclusive and multilateral manner. Compared with the partial multilateral approach of OEC/G20, the global BEPS actions launched by the UN will better address the BEPS concerns and restore the integrity of international tax principles of single tax, neutrality, transparency and fairness.

\section{Reconsidering the International Tax Regime: A Multilateral Solution}

As stated above, in our opinion it is time to re-evaluate the benefits principle. Most of the current issues can be solved if we taxed passive income primarily at source and active income primarily at residence.

For passive income, the number of source jurisdictions is much smaller than residence jurisdictions. Because most individuals are relatively risk averse, portfolio investment flows overwhelmingly to a small number of countries - the US, the EU and Japan. If these three jurisdictions could impose a withholding tax on all outbound payments, most of the problem of taxing passive income could be resolved. Crucially, money cannot stay in tax havens and earn decent rates of return, so the cooperation of tax havens in not needed.

In the case of active income, about $90 \%$ of large multinationals are headquartered in G20 countries, and none of those countries has a corporate tax rate below $20 \%$. If the G20 taxed their multinationals (based on where the headquarters are located) on a current basis and restricted the ability to move the headquarters, the problem of taxing active income would be largely resolved as well. This would take care of the Apple and Caterpillar problems, because all of their offshore income would be subject to current US taxation. ${ }^{39}$

As the first author has argued elsewhere, this multilateral approach takes care of the three common critiques of abolishing deferral of tax on active income. These critiques are based on economic neutrality, competitive-

38. The UN is based on the principle of sovereign equality of all its members. See UN Charter.

39. Some of the BEPS action items (8-10) seek to address the types of profit shifting engaged in by Apple and Caterpillar, but as argued above they are not very effective. 
ness and the risk of corporate expatriations. If all our major competitors are subject to the same regime, this resolves all three problems. ${ }^{40}$

But what if the other countries in the G20 are unlikely to coordinate with the US? In that case, the solution is 'constructive unilateralism': unilateral action by the US that leads to action by other jurisdictions.

The precedent is the adoption of the CFC rules, which proves (among other examples) that such action can be both possible and effective in pushing other countries to adopt similar rules. ${ }^{41}$

Before 1961, no country taxed the foreign source income of subsidiaries of its multinationals, because residence countries believed they lacked both source and residence jurisdiction over foreign source income of foreign corporations. However, in 1961 the Kennedy Administration proposed taxing all income of 'controlled foreign corporations' (CFCs) by using a deemed dividend mechanism that was copied from the FPHC rules. $^{42}$

While this proposal was rejected, the resulting compromise (Subpart F, 1962) aimed at taxing income of CFCs that was unlikely to be taxed by source countries either because it was mobile and could be earned anywhere (passive income), or because it was structured to be earned in low-tax jurisdictions (base company income).

Initially, the adoption of Subpart F seemed to have put US-based multinationals at a competitive disadvantage, because no other country had such rules. But gradually this picture changed. The US was followed by Germany (1972), Canada (1975), Japan (1978), France (1980), United Kingdom (1984), New Zealand (1988), Australia (1990), Sweden (1990), Norway (1992), Denmark (1995), Finland (1995), Indonesia (1995), Portugal (1995), Spain (1995), Hungary (1997), Mexico (1997), South Africa (1997), South Korea (1997), Argentina (1999), Brazil (2000), Italy (2000), Estonia (2000), Israel (2003), Turkey (2006), and China (2008). Many other countries, such as India, are considering adopting such rules. As a result, most of our trading partners now have CFC rules.

Moreover, the later adopters improved on the US in two principal ways. First, they rejected the deemed dividend mechanism, which can lead to many unforeseen complications, in favour of taxing the shareholders on a pass-through basis. Second, they generally explicitly incorporate the effective foreign tax rate into the determination whether a CFC will be subject to current tax. This is better than the US rule that is based solely on the type of income, because after 1980 it became quite easy to earn active income that is not subject to tax. ${ }^{43}$

40. R. Avi-Yonah, 'Hanging Together: A Multilateral Approach to Taxing Multinationals', in T. Pogge and K. Mehta (eds.), Global Tax Fairness, (2016) at 113.

41. We do not think unilateral action is possible on the evasion front, but as explained above, coordinated withholding taxes by the US and the EU should work.

42. R. Avi-Yonah, 'The Deemed Dividend Problem', 4 J. Tax. Glob. Trans. 33 (2004), also in Proceedings of the National Tax Assoc. Annual Meeting (2004).

43. See Avi-Yonah (2000), above n. 2.
The result is that the CFCs of EU-based multinationals are currently generally subject to tax at similar or higher rates than US-based ones, ${ }^{44}$ despite the non-taxation of dividends from active income under territoriality. This is therefore a classic example of constructive unilateralism. The US led and others followed, and the end result is that most multinationals are subject to similar effective tax rates, with no competitive disadvantage or advantage. ${ }^{45}$ The result is a world in which there is much less double non-taxation than in the absence of CFC rules.

Unfortunately, in the US Subpart F has been critically undermined by the adoption of check the box and the CFC to CFC exception, resulting in $\$ 2$ trillion of lowtaxed accumulated earnings offshore by US multinationals. ${ }^{46}$ This cannot happen in other countries with tougher CFC rules, and is a major part of the explanation why despite rampant tax competition most OECD members did not see the sharp drops in overall corporate tax revenues that are seen in developing countries.

The main argument in favour of territoriality (i.e. exempting dividends paid by US CFCs from tax upon receipt by their parents) is the lock-out problem. About $\$ 2$ trillion in low-taxed foreign source income are in CFCs that cannot repatriate them because of the 35\% tax on repatriations and the absence of foreign tax credits. $^{47}$ We know this is a real problem because of the effectiveness of the 2004-2005 amnesty and because of various attempts by multinationals to avoid the rule (e.g. via inversions, 'killer Bs', short-term loans, etc.). ${ }^{48}$

But it is less clear that the solution is a participation exemption. Why not abolish deferral and let the dividends flow back tax-free?

We would argue that this is a good opportunity for 'constructive unilateralism'. No G20 country has a corporate tax rate below $20 \%$. If the US reduced the corporate tax to, say, $28 \%$, and at the same time abolished deferral, the likely response by other G20 members like Germany or France would be to follow suit. ${ }^{49}$ They need the extra revenue more than we do, and concerns about competitiveness would be alleviated by the US move, like they were in the original CFC context.

It should be remembered that the other G20 have more effective CFC rules than we do, and those CFC rules already act as a de facto worldwide system with a mini-

44. See R.S. Avi-Yonah and Y. Lahav, 'The Effective Tax Rate of the Largest US and EU Multinationals' (October 25, 2011), U of Michigan Law \& Econ, Empirical Legal Studies Center Paper No. 11-015; U of Michigan Public Law Working Paper No. 255. Available at SSRN: <https://ssrn. com/abstract=1949226> or <http://dx.doi.org/10.2139/ssrn. 1949226>.

45. Ibid.

46. K.A. Clausing, 'The Effect of Profit Shifting on the Corporate Tax Base', Tax Notes, 25 January 2016

47. Ibid

48. US Senate PSI, <RepatriatingOffshoreFundsReportOct202011wExhibitsFINAL.pdf>.

49. $28 \%$ is the rate at which a revenue neutral corporate tax reform can be achieved if we abolished the three major corporate tax expenditures (deferral, accelerated depreciation and the domestic manufacturing deduction). Available at: <https://www.fas.org/sgp/crs/misc/R44220. $p d f>$ 
mum tax: If the foreign tax is below a set level (e.g. 25\% in Germany or $20 \%$ in Japan), the CFC rules kick in to tax the income. The result is that there is much less lock out because most low-taxed foreign income is taxed by the CFC rules. The change to a worldwide system would be much less radical than usually envisaged. This is why for both the UK and Japan there was no significant increase in repatriations after they adopted territoriality in 2009. ${ }^{50}$

But should the US not adopt a minimum but lower tax on foreign source income for competitiveness reasons? This is what both the Obama and Camp proposals envisage. Obama suggests a $28 \%$ corporate tax on domestic profits and a 19\% tax on foreign income, while Camp proposed a $25 \%$ tax on domestic profits and a $12.5-15 \%$ tax on foreign income.

The problem, of course, is that such a gap would still encourage US-based MNEs to shift profits overseas, with no repatriation tax to deter them. We can always fall back to such a system if needed. But for now we would suggest taxing all income at the same rate, and if that rate has to be lower, so be it. As long as it is above $20 \%$ we do not think we will be outside G20 norms, and a rate in the $20-25 \%$ range will not put our MNEs at a significant competitive disadvantage given the effective minimum tax imposed by the CFC rules of our trading partners.

It is impossible to predict what will happen, but the history described above suggests that there is a good chance that other G20 countries will follow us if we abolish deferral at a lower rate. ${ }^{51}$ And if that happens, all the usual objections to worldwide taxation (competitiveness, inversions and the various neutralities) lose their force. We do not think there is a significant risk involved in this move, and the potential upside is quite large.

\section{Conclusion}

The benefits principle should be reconsidered in light of the reality of globalisation. We should tax passive income primarily at source and active income primarily at residence. This will enable the large economies to address both individual tax evasion and corporate tax avoidance.

These problems must be addressed if we are to continue to maintain and expand the benefits of globalisation. The US public support of globalisation hinges on the existence of a social insurance safety net. If the rich and large corporations are not perceived to pay their fair share, the public's willingness to pay tax to support this safety net is eroded. Once a culture of not paying taxes is established, it is very hard to change. We need to do something about both tax evasion and avoidance before it is too late.

50. S.E. Shay, J.C. Fleming \& R.J. Peroni, 'Territoriality in Search of Principles and Revenue: Camp and Enzi', 141 Tax Notes 173 (2013); 72 Tax Notes Int. 155 (2013). Available at SSRN: <http://ssrn.com/abstract= 2340615>.

51. See the most recent proposal of the EU Commission to tax currently CFC profits that are subject to an effective tax rate below $40 \%$ of the residence country rate if over $50 \%$ of the CFC's income is either passive or derived from sales to related parties. Council of the European Union Doc. 14544/15 (2 December 2015) and Doc.14544/15 Add 1 (2 December 2015), Art. 9. See also EU Commission, 'Proposal for a Council Directive laying down rules against tax avoidance practices that directly affect the functioning of the internal market', COM (2016) 26 final; EU Commission, 'Anti Tax Avoidance Package', COM (2016) 23 final. But see 'US blasts Brussels over tax probe bias', Financial Times, 29 January 2016. Hopefully the next US Administration will take a more cooperative attitude. 